\title{
GESTÃO DE RESÍDUOS SÓLIDOS: UM ESTUDO DE CASO NO CAMPUS UNIVERSITÁRIO DA UNEMAT DE TANGARÁ DA SERRA - MT
}

\author{
Fernanda Freire de Oliveira ${ }^{1}$ \\ Flávio Amaral Oliveira ${ }^{2}$
}

\begin{abstract}
RESUMO
A gestão de resíduos sólidos consiste em práticas adotadas para o gerenciamento da produção, coleta, armazenamento e destinação dos resíduos sólidos gerados num determinado ambiente, visando-se estabelecer práticas que levam a explorar o potencial de reaproveitamento dos resíduos sólidos, diminuindo-se o impacto destes ao meio ambiente. Desta forma, esta pesquisa aborda sobre a gestão de resíduos sólidos no campus da Universidade do Estado de Mato Grosso (UNEMAT) da cidade de Tangará da Serra - MT. Teve como objetivos específicos identificar as normas e políticas de resíduos sólidos, identificar as práticas adotadas pelo campus para a gestão de resíduos sólidos, quais sãos os principais resíduos sólidos gerados pelas atividades educacionais e a destinação dada a estes resíduos. Para a realização do trabalho foi realizado a aplicação de um questionário para identificar a atual situação do campus em relação à geração de resíduos sólidos e realizado visita ao campus para identificar como tais resíduos são depositados e armazenados, até à coleta. Os resultados da pesquisa apontam que o campus da UNEMAT de Tangará da Serra - MT, no momento, não adota nenhuma prática para a gestão dos resíduos sólidos, e necessita adequar-se quanto as responsabilidades descritas na Política Nacional de Resíduos Sólidos.
\end{abstract}

Palavras-chave: Resíduos Sólidos. Gestão Ambiental. UNEMAT. Tangará da Serra.

\section{INTRODUÇÃO}

Em 1972 na Conferência de Estocolmo apresentou-se um novo conceito de desenvolvimento propondo-se o alinhamento das necessidades dos homens ao aspecto econômico, social e ambiental, a partir dessa concepção emerge-se o conceito de "abordagem do ecodesenvolvimento", posteriormente renomeado para desenvolvimento sustentável. Esta expressão teve pela primeira vez uma definição mais elaborada, somente em 1987 no informe Brundtland (Nosso Futuro Comum) produzido pela Comissão Mundial para o Meio Ambiente e Desenvolvimento (CMMAD) (DIAS, 2006).

De acordo com Dias (2006), a apresentação conceitual o desenvolvimento sustentável desdobra-se em dois subconceitos. O primeiro é quanto às "necessidades", principalmente aquelas essências à sobrevivência dos pobres e deve estar na agenda de todos os países, por

\footnotetext{
${ }^{1}$ Acadêmica do curso de Ciências Contábeis da UNEMAT - Campus de Tangará da Serra, e-mail: fer_freire22@hotmail.com.

${ }^{2}$ Professor do curso de Ciências Contábeis da UNEMAT - Campus de Tangará da Serra, e-mail: flavioamaral@unemat.br. 
Gestão de resíduos sólidos: um estudo de caso no campus universitário da UNEMAT de Tangará da Serra - MT

Fernanda Freire de Oliveira

Flávio Amaral Oliveira

sua vez, o segundo é quanto o avanço tecnológico e pela organização social, os quais limitam o meio ambiente, impedindo-o de atender às necessidades presentes e futuras.

Dentre os pontos discutidos sobre desenvolvimento sustentável e meio ambiente, encontra-se a geração de resíduos sólidos que tem seu conceito definido pelo artigo primeiro, inciso XVI da Lei $n^{o}$ 12.305/2010 (Política Nacional de Resíduos Sólidos), como todo e qualquer material, substância, objeto ou bem descartado, cuja destinação final se procede, se propõe proceder ou se está obrigado a proceder, nos estados sólido ou semissólido, bem como gases contidos em recipientes e líquidos cujas particularidades tornem inviável o seu lançamento na rede pública de esgotos ou em corpos d'água, ou exijam para isso soluções.

No Brasil segundo dados da décima edição do panorama atual sobre a geração de resíduos sólidos, elaborado pela Associação Brasileira de Empresas de Limpeza Pública e Resíduos Especiais (ABRELPE), constatou-se que em 2012, foram geradas quase 64 milhões de toneladas de resíduos sólidos, o que equivale a uma geração de $383 \mathrm{~kg} / \mathrm{ano}$ per capita. Tal produção representou um acréscimo de 1,3\% de lixo por habitante em relação a 2011, índice superior à taxa de crescimento populacional registrada no mesmo período, que foi de $0,9 \%$.

O levantamento aponta ainda que do montante gerado, mais de 3 mil cidades brasileiras enviaram quase 24 milhões de toneladas de resíduos para destinos considerados inadequados, o equivalente a 168 estádios do Maracanã lotados de lixo. Quanto aos investimentos de recursos no setor, verificou-se um aumento de $7 \%$ aplicados pelas administrações públicas à coleta de resíduos sólidos, uma média de $\mathrm{R} \$ 11,00 /$ habitante/mês. Porém o estudo conclui, que este valor ainda é considerado baixo ante as necessidades geradas pelo aumento populacional e do consumo da sociedade brasileira.

Destaca Jacobi (2003), que neste contexto socioambiental, as instituições de ensino superior (IES), estão inevitavelmente inseridas, necessitando-se da sua atenção aos temas, pois a dimensão ambiental envolve um conjunto de atores do universo educativo, potencializando-se o engajamento dos diversos sistemas de conhecimento, a capacitação de profissionais e a comunidade universitária de forma interdisciplinar.

Quanto à ampla missão de preparação do conhecimento dos estudantes afirmam Tauchen e Brandi (2006) que as IES podem e devem utilizá-los para construir o desenvolvimento de uma sociedade sustentável e justa, desde que tais instituições incorporem práticas e princípios de sustentabilidade, atingindo todos os níveis (professores, funcionários e alunos). As IES tem um importante papel a cumprir rumo ao desenvolvimento sustentável, 
Gestão de resíduos sólidos: um estudo de caso no campus universitário da UNEMAT de Tangará da Serra - MT

Fernanda Freire de Oliveira

Flávio Amaral Oliveira

servindo de exemplo a toda a sociedade. Elas devem preocupar-se que a idéia de sustentabilidade reflita em sua infraestrutura física, administração e linha pedagógica (JÚNIOR CASAGRANDE; DEEKE, 2008).

Além do importante papel destacado no âmbito sócio educacional/ambiental pelas IES, ressalta-se também, que a tais instituições, se incubem a necessidade gradativa de adequar-se a implantação da Política Nacional dos Resíduos Sólidos, que dentre os princípios estabelecidos em seu artigo sexto, tem: a cooperação entre as diferentes esferas (poder público, setor empresarial e demais segmentos) e a responsabilidade compartilhada pelo ciclo de vida dos produtos.

Desta forma, com esta pesquisa buscou-se identificar quais são as práticas de gestão de resíduos sólidos adotadas no campus da UNEMAT de Tangará da Serra - MT, tendo como objetivos específicos: pesquisar e identificar sobre as normas e políticas de resíduos sólidos, identificar se existe no campus de Tangará da Serra - MT programa (as) de gestão de resíduos sólidos implantado (os); identificar quais sãos os principais resíduos sólidos gerados pelas atividades no campus e a identificar qual destinação dada aos resíduos sólidos gerados no campus.

\section{REFERENCIAL TEÓRICO}

\subsection{Gestão Ambiental e Sistemas de Gestão Ambiental}

Para discutir-se sobre Gestão Ambiental (GA) e Sistemas de Gestão Ambiental (SGA), faz-se necessário o apresentação de um outro conceito, Responsabilidade Social e Ambiental. Para Bush e Ribeiro (2009), a responsabilidade social conduz às organizações ao compromisso e responsabilidade com a humanidade, respeitando-se os direitos humanos, justiça, dignidade e ao planeta, para garantir a sustentabilidade da rede da vida.

A Gestão Ambiental é o processo pelo qual uma organização através da definição de políticas ambientais, estrutura e organiza o seu sistema de gestão para reduzir os impactos sobre o meio ambiente. Levando-se em conta todas as variáveis de um processo de gestão, como o estabelecimento de políticas, planejamento, um plano de ação, alocação de recursos, decisão, coordenação e controle, visando-se principalmente o desenvolvimento sustentável. Desenvolvendo-se dentro do sistema da organização mecanismos para minimizar tais impactos ambientais (FERREIRA, 2004). 
Gestão de resíduos sólidos: um estudo de caso no campus universitário da UNEMAT de Tangará da Serra - MT

Fernanda Freire de Oliveira

Flávio Amaral Oliveira

No mesmo sentido, Tinoco e Kraemer (2004), destacam como sendo um sistema que inclui a estrutura organizacional, atividades de planejamento, responsabilidades, práticas, procedimentos, processos e recursos para desenvolver, implementar, atingir, analisar criticamente e manter a política ambiental. É o que a organização faz para minimizar ou eliminar os efeitos negativos provocados no meio ambiente por suas atividades, o como mobiliza-se interna e externamente em pró da qualidade ambiental. Sendo essencial para atingir a gestão ambiental que a organização passe por uma mudança cultural, pela revisão de seus paradigmas.

Dentro do conceito de gestão ambiental encontram-se dois outros importantes conceitos para o entendimento do tema, a política ambiental e impacto ambiental. O primeiro é conceituado como uma declaração da organização, expondo suas invenções e princípios em relação ao seu desempenho ambiental global, que prevê uma estrutura para a ação e definição de seus objetivos e metas ambientais. Já o segundo trata-se de qualquer alteração produzida pelos homens e suas atividades, nas relações constitutivas do ambiente, que excedam a capacidade de absorção do mesmo (ISO 14.001, apud ASSUMPÇÃO, 2005; KRAEMER, TINOCO, 2004).

A definição de impacto ambiental está presente no art. $1^{\circ}$ da Resolução ${ }^{\circ} 1$ de 1986 do CONAMA (Conselho Nacional do Meio Ambiente):

Considera-se impacto ambiental qualquer alteração das propriedades físicas, químicas e biológicas do meio ambiente, causada por qualquer forma de matéria ou energia resultante das atividades humanas, que direta ou indiretamente, afetam-se: a saúde, a segurança e o bem-estar da população; as atividades sociais e econômicas; a biota; as condições estéticas e sanitárias do meio ambiente e a qualidade dos recursos naturais.

Segundo Ferreira (2004) a operacionalização da gestão dá-se de quatro atividades principais: a reciclagem, recuperação, prevenção e monitoramento. A reciclagem são ações que propiciam a reutilização de materiais e/ou produtos, de modo a estender seu ciclo de vida e diminuir os problemas com o depósito de dejetos ou de emissão de poluentes. $\mathrm{Na}$ recuperação busca-se sanar os danos provocados pela poluição, visando-se deixar o meio ambiente em condições melhores do que se encontrava antes da ação poluidora, ou quando não possível recuperá-lo em sua totalidade, pelo menos melhorando-se as condições ambientais atuais.

Já as ações específicas com o objetivo de evitar ou proteger o meio ambiente de qualquer agressão causada pelo homem ou, até mesmo, causada pela própria natureza é 
Gestão de resíduos sólidos: um estudo de caso no campus universitário da UNEMAT de Tangará da Serra - MT

Fernanda Freire de Oliveira

Flávio Amaral Oliveira

entendido como prevenção. Por último, o monitoramento compreende às ações de controle e acompanhamento dos níveis de poluição e dos programas de prevenção e também de recuperação ambiental, quando for o caso.

Um Sistema de Gestão Ambiental (SGA) é um conjunto de procedimentos, instruções de trabalho e controles, que visam assegurar a execução da política ambiental estabelecida pela organização. Originaram-se do desenvolvimento dos sistemas de qualidade. Para a sua implantação faz-se necessário a identificação de todos os aspectos pertinentes as atividades, produtos e serviços das organizações e seus respectivos impactos ao meio ambiente (KRAEMER; TINOCO, 2004).

Segundo os autores acima citados e Dias (2006) para a institucionalização de um SGA na organização necessita-se executar algumas etapas apresentadas como princípios, sendo elas:

- Estabelecimento da política ambiental - é o primeiro passo para a implantação do SGA;

- O planejamento - estabelecer e manter procedimentos para identificar os aspectos ambientais produzidos na organização e avaliar seu impacto no meio ambiente;

- Implementação - as regras, responsabilidades e autoridades devem estar definidas, documentadas e comunicadas a todos, de forma a garantir sua aplicação;

- Verificação e ações corretivas - a organização deve definir, estabelecer e manter procedimentos de controle e medição das características-chave de seus processos, de não conformidades, dos registros ambientais e da auditoria do SGA;

- Revisão pela direção - cabe à direção, com frequência definida por ela mesmo, rever e avaliar o SGA para garantir sua adequabilidade, conveniência e eficácia.

Quanto a este último aspecto Assumpção (2005), destaca que a alta direção tem um papel essencial no bom desenvolvimento do SGA e é necessário que a mesma tenha a visão clara sobre o sistema. Pois caso isso não aconteça, na primeira ocorrência de dificuldade, todo o trabalho pode interromper-se, e na sua retomada as dificuldades poderão ser maiores.

Depois de implantando o SGA por uma organização, esta poderá iniciar um processo de certificação das suas práticas ambientais por uma entidade independente. As primeiras normais ambientais para as certificações de organizações originam-se na década de 90 , dentre 
Gestão de resíduos sólidos: um estudo de caso no campus universitário da UNEMAT de Tangará da Serra - MT

Fernanda Freire de Oliveira

Flávio Amaral Oliveira

as quais comenta-se as normais ambientais ISO (Internaticonal Organization for Standadization) e as normas elaboradas pelo British Standars Institute, pois após a elaboração destas duas, proliferou-se uma série de normas de SGA nacionais, como da França, Espanha, África do Sul, entre outros. (ASSUMPÇÃO, 2005; TINOCO, KRAEMER, 2004).

Em 1992 foi publicado pelo British Standars Institute a norma BS 7750, a qual fundamentou-se na norma BS 5750 - Sistema Padrão de Gerenciamento de Qualidade. Por sua vez a norma ISO 14.001 de certificação ambiental, apresenta similaridade estrutural e desdobrou-se da norma BS 5750.A ISO é uma organização internacional fundada em 1946 para desenvolver padrões de industrialização, de comércio, de comunicação, entre outros (ASSUMPÇÃO, 2005; TINOCO, KRAEMER, 2004).

Explica Assumpção (2005), que as normas da família ISO 14.000, é uma série de padronizações para as questões ambientais de qualquer tipo de organização, foi elaborada também em 1992, quando no ano anterior (1991) a ISO instituiu o Grupo Estratégico Consultivo Sobre o Meio Ambiente (SAGE), que criou o Comitê Técnico 207 (TC-207) responsável pela elaboração da ISO 14.000. Mas foi somente em 1996 que homologou-se a primeira norma da família, a ISO 14.001 que trata da implantação do "Sistema de Gestão Ambiental; Especificações e Diretrizes para uso". No Brasil a homologação deu-se pela Associação Brasileira de Normas Técnicas (ABNT) - ABNT-ISO 14.001.

A norma ISO 14.001 foi elaborada com base na sistemática do princípio do ciclo PDCA (Plan, Do, Check e Action), ou seja, planejar, executar e agir, também conhecido como ciclo da melhoria continua. O planejamento envolve o estabelecimento dos objetivos e processos necessários para atingir os resultados de acordo com a política ambiental da organização. A execução corresponde à implementação dos processos. O monitoramento e medição destes em conformidade com a política ambiental, objetivos, metas, requisitos legais e outros, é a verificação. Finalizando-se com a ação que envolve a execução de ações para melhorar continuamente o desempenho do SGA (TAUCHEM; BRANDLI, 2006).

A partir do exposto destaca-se que para a implantação de um SGA numa organização pode orientar-se por um sistema de certificação ambiental, porém como passo fundamental a esta institucionalização, necessita-se que a organização identifique e conheça todos os agentes ambientais por ela produzidos, entenda os impactos que estes causam no meio ambiente e estabeleça uma política ambiental clara, que seja internalizada e seguida por aqueles ligados 
Gestão de resíduos sólidos: um estudo de caso no campus universitário da UNEMAT de Tangará da Serra - MT

Fernanda Freire de Oliveira

Flávio Amaral Oliveira

direta ou indiretamente a organização. Garantindo-se assim um resultado positivo e proativo na implantação do SGA.

\subsection{Gestão de Resíduos Sólidos}

De acordo com Dejamovic (1995), até chegar à expressão resíduos sólidos, foi a palavra lixo quem perpetuou. Lixo era o conceito dado aos subprodutos do sistema produtivo, que deveriam ser apenas descartado, pois não tinha qualquer valor. Contudo, com o crescente aumento na produção de lixo pela sociedade moderna, percebeu-se, que era preciso encontrar outras soluções ao destino final do lixo. De onde veio a concepção dos resíduos sólidos, que passa a tratar o lixo pelas suas características, possibilitando-se o seu reaproveitamento no próprio processo produtivo, passando a ter valor econômico agregado.

Segundo o Dejamovic (1995), a gestão de resíduos sólidos passou por três fases internacionalmente. A primeira que durou até o início da década 70, priorizava apenas garantir a disposição dos resíduos, os quais eram destinados a aterros de céu aberto. Estes passaram a ser erradicados na maioria dos países da OCDE - Organização Para a Cooperação e Desenvolvimento Econômico, organização da qual o Brasil faz parte. Já a segunda fase, a partir de meados da década de 70, os resíduos sólidos gerados passam a ser encaminhados a aterros sanitários ou incineração. E iniciam-se as práticas de reciclagem e recuperação dos resíduos.

É durante está segunda fase, que em 1975, os países da OCDE, consolidaram as práticas de gestão de resíduos sólidos, publicando pela primeira vez, as prioridades relacionadas a estas práticas, sendo na ordem: redução da produção de resíduos, reciclagem do material, incineração com reaproveitamento da energia e disposição em aterros sanitários controlados. Já a última fase, no final da década de 80, é marcada, pela definição de reutilização, assim, antes de diminuir a produção de determinados bens, prioriza-se, que eles não sejam gerados (DEJAMOVIC, 1995).

No Brasil, segundo a Política Nacional de Resíduos Sólidos (PNRS), os resíduos sólidos estão classificados no Artigo 13, quanto à sua origem e quanto à periculosidade. Quanto à origem o inciso I estabelece que podem ser:

a) resíduos domiciliares - os originários de atividades domésticas em residências urbanas;

b) resíduos de limpeza urbana - os originários da varrição, limpeza de logradouros e vias públicas e outros;

c) resíduos sólidos urbanos: os englobados nas alíneas "a" e "b"; 
Fernanda Freire de Oliveira

Flávio Amaral Oliveira

d) resíduos de estabelecimentos comerciais e prestadores de serviço: os gerados nessas atividades excetuados os referidos nas alíneas "b", "e", "g", "h" e “j”;

e) resíduos dos serviços públicos de saneamento: os gerados nessas atividades, excetuados os referidos na alínea "c";

f) resíduos industriais: os gerados nos processos produtivos e instalações industriais; g) resíduos de serviços de saúde: os gerados nos serviços de saúde, conforme definido em regulamento ou em normas estabelecidas pelos órgãos do Sisnama e do SNVS;

h) resíduos da construção civil: os gerados nas construções, reformas, reparos e demolições de obras de construção civil, incluídos os resultantes da preparação e escavação de terrenos para obras civis;

i) resíduos agrossilvopastoris: os gerados nas atividades agropecuárias e silviculturais, incluídos os relacionados a insumos utilizados nessas atividades;

j) resíduos de serviços de transportes: os originários de portos, aeroportos, terminais alfandegários, rodoviários e ferroviários e passagens de fronteira;

k) resíduos de mineração: os gerados na atividade de pesquisa, extração ou beneficiamento de minérios;

Já quanto à periculosidade, a PNRS institui no inciso II que podem ser perigosos ou não. Considerando-se como perigosos aqueles que em razão de características do tipo inflamabilidade, corrosividade, reatividade, toxidade, patogenidade, carcinogenicidade, teratogenicidade e mutagenicidade, apresentam risco a saúde pública ou à qualidade ambiental. A PNRS não define estas características, todavia, a especificidade delas encontrase definida pela Norma Técnica ABNT - NBR 10.004/2004. Para a PNRS os RS não perigosos são aqueles que não se encaixam nos critérios de periculosidade.

ABNT - NBR 10.004/2004 por sua vez classifica os RS em a) resíduos classe I Perigosos e b) resíduos classe II - Não Perigosos (resíduos classe II A - Não Inertes e resíduos classe II B - Inertes). Os resíduos classe II A - Não Inertes são todos aqueles que não se classificam como classe I - perigosos e nem classe II A - Não Inertes, podem ter propriedades tais como: biodegradabilidade, combustibilidade ou solubilidade em água. Já Os RS classe II B - Inertes são aqueles que submetidos a um contato dinâmico e estático com água destilada ou desionizada, à temperatura ambiente, não tiverem nenhum de seus componentes solubilizados a concentrações superiores aos padrões de potabilidade de água, excetuando-se aspecto, cor, turbidez, dureza e sabor.

Quanto às características de periculosidade dos resíduos classe I, de acordo com a ABNT - NBR 10.004/2004:

- Inflamabilidade: quando o resíduo líquido, não líquido, oxidante ou um gás comprimido e ter a capacidade de ser inflamável, ou seja, estimular/sofrer combustão e queimar; 
Gestão de resíduos sólidos: um estudo de caso no campus universitário da UNEMAT de Tangará da Serra - MT

Fernanda Freire de Oliveira

Flávio Amaral Oliveira

- Corrosividade: quando o resíduo líquido ou a solução aquosa apresenta a capacidade de coroer, logo, corrosiva;

- Reatividade: quando de maneira em gerar ser normalmente instável e em contato com a água: reagir violentamente formar misturas potencialmente explosivas, gerar gases, vapores e fumos tóxicos em quantidades suficientes para provocar danos à saúde pública ou ao meio ambiente; ser capaz de produzir reação explosiva ou detonante sob a ação de forte estímulo, ação catalítica ou temperatura em ambientes confinados; ser explosivo, definido como uma substância fabricada para produzir um resultado prático, etc., ser reativo.

- Toxicidade: apresentar em sua propriedade valores de toxicidade superiores ao estipulado pela norma ou ainda, em contato com outras substâncias, também demonstrar característica de toxicidade;

- Patogenicidade: um resíduo é caracterizado como de maneira geral quando uma amostra representativa dele contiver ou se houver suspeita de conter, micro-organismos patogênicos, proteínas virais, organismos geneticamente modificados, cloroplastos, mitocôndrias, toxinas, etc.

A toxicidade ainda é definida como uma propriedade potencial que o agente tóxico possui de provocar, em maior ou menor grau, um efeito adverso em consequência de sua interação com o organismo. Já o agente tóxico é qualquer substância ou mistura cuja inalação, ingestão ou absorção cutânea tenha sido cientificamente comprovada como tendo efeito adverso (tóxico, carcinogênico, mutagênico, teratogênico ou ecotoxicológico) (ABNT - NBR $10.004,2004)$.

Os efeitos adversos aos agentes tóxicos originam-se de seus agentes, que são: agente teratogênico: qualquer substância, mistura, organismo, agente físico ou estado de deficiência que, estando presente durante a vida embrionária ou fetal, produz uma alteração na estrutura ou função do indivíduo dela resultante. Agente mutagênico: qualquer substância, mistura, agente físico ou biológico cuja inalação, ingestão ou absorção cutânea possa elevar as taxas espontâneas de danos ao material genético e ainda provocar ou aumentar a frequência de defeitos genéticos. O agente carcinogênico é aquele cuja inalação ingestão e absorção cutânea possa desenvolver câncer ou aumentar sua frequência e o agente ecotóxico são substâncias ou misturas que apresentem ou possam apresentar riscos para um ou vários compartimentos ambientais (ABNT - NBR 10.004, 2004). 
Gestão de resíduos sólidos: um estudo de caso no campus universitário da UNEMAT de Tangará da Serra - MT

Fernanda Freire de Oliveira

Flávio Amaral Oliveira

Os RS estão ordenados segundo a Lista Brasileira de Resíduos Sólidos, estabelecida pela Instrução Normativa No 13/2012 do IBAMA, em seu Anexo I, por uma sequência de seis números. O primeiro grupo identifica o capítulo a qual pertence o resíduo, o segundo o subcapítulo e o terceiro, o resíduo em si, conforme esboçado na Figura 6. Uma observação importante, é que quando esta sequência de números estiver acompanhada de asterisco (*), indicará que aquele é um resíduo classificado como perigoso, como por exemplo, o RS “0104 07 (*) Resíduos contendo substâncias perigosas, resultantes da transformação física e química de minérios não metálicos".

Figura 1 - Exemplo de como são classificados os RS

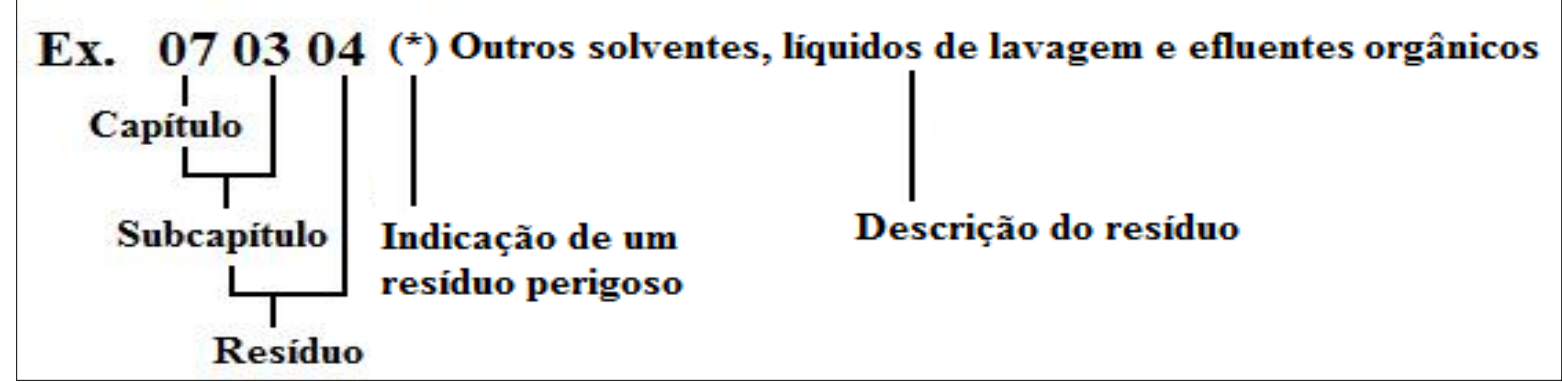

Fonte: IBAMA (2012).

A PNRS traz importantes conceitos que norteiam o entendimento sobre RS. Dentre os quais destacam-se a apresentação conceitual sobre a coleta seletiva, logística reversa, reciclagem, rejeitos, reutilização, gerenciamento de resíduos sólidos e disposição e destinação ambientalmente adequada. A coleta seletiva é a coleta de resíduos sólidos segregados conforme sua constituição ou composição.

Dentre os RS materiais como agrotóxicos (resíduos e embalagens), pilhas, baterias, pneus, óleos lubrificantes (resíduos e embalagens), lâmpadas fluorescentes e produtos eletrônicos e seus componentes, após o consumo devem retornar diretamente à indústria de origem, sem usar do sistema público de limpeza urbana, este é o processo de logística reversa. Esse retorno fica condicionado inclusive aos distribuidores, importadores e comerciantes, os quais fazem o comércio desse grupo de produtos (PNRS, 2010).

Ainda de acordo com a PNRS a reciclagem e a reutilização são processos de reaproveitamento dos RS, a diferença entre ambos, está em existir ou não processo de transformação ou alteração de propriedades físicas, físico-químicas ou biológicas. Na reciclagem, ocorre a transformação/alteração visando-se gerar insumos ou novos produtos. Já a reutilização não há esse processo, o produto é reaproveitado em seu estado natural. Exemplificando-se os dois processos, têm-se, a reutilização: reaproveitamento de garrafas 
Gestão de resíduos sólidos: um estudo de caso no campus universitário da UNEMAT de Tangará da Serra - MT

Fernanda Freire de Oliveira

Flávio Amaral Oliveira

pets em trabalhos artesanais, e a reciclagem, no aproveitamento de sacos plásticos diversos oriundos das atividades de consumo, para a geração de sacos de lixo.

O gerenciamento de resíduos sólidos apresenta-se como:

conjunto de ações exercidas, direta ou indiretamente, nas etapas de coleta, transporte, transbordo, tratamento e destinação final ambientalmente adequada dos resíduos sólidos e disposição final ambientalmente adequada dos rejeitos, de acordo com plano municipal de gestão integrada de resíduos sólidos ou com plano de gerenciamento de resíduos sólidos, exigidos na forma desta Lei; (POLÍTICA NACIONAL DE RESÍDUOS SÓLIDOS, 2010).

Quanto à disposição e destinação final ambientalmente adequada, referem-se respectivamente ao "fim" adequado dado aos RS. De acordo com a PNRS, ambas devem respeitar os procedimentos estabelecidos por órgãos como o Sisnama - Sistema Nacional do Meio Ambiente, SNVS - Sistema Nacional de Vigilância Sanitária e Suasa - Sistema Nacional de Atenção à Sanidade Agropecuária. A disposição refere-se aos rejeitos, os quais não têm outro caminho a seguir, restando-se apenas a entrega em aterros. Por fim, a destinação compreende encaminhar os RS a reutilização, reciclagem, compostagem, recuperação, o aproveitamento energético ou até mesmo a própria disposição final.

Outro conceito importante, mas que não encontra-se presente na PNRS é sobre a área de "transbordo" ou "estação de transferência", que é definida segundo Mansur e Monteiro (2001, apud CUNHA e CAIXETA FILHO, 2002) são locais onde os caminhões coletores descarregam sua carga em veículos com carrocerias de maior capacidade para que, posteriormente, sejam enviadas até o destino final. Objetiva-se com as estações é reduzir o tempo gasto no transporte e, consequentemente, os custos com o deslocamento do caminhão coletor até ao ponto de disposição final dos resíduos.

\section{METODOLOGIA}

Quanto aos objetivos a pesquisa foi descritiva, pois realizou-se um diagnóstico sobre a atual situação do campus, em relação a geração de resíduos sólidos. O universo da pesquisa é o campus da universidade UNEMAT de Tangará da Serra - MT, que conta atualmente com 2.154 acadêmicos regularmente matriculados, 245 colaboradores (professores e servidores) e 49 terceirizados (serviço de segurança, limpeza, cantina e serviço de cópias). Tendo como sujeitos analisados: 1) para situar-se em relação as políticas adotadas quanto aos RS a nível da instituição o diretor do campus e 2) para a análise da geração de RS, as atividades acadêmicas 
Gestão de resíduos sólidos: um estudo de caso no campus universitário da UNEMAT de Tangará da Serra - MT

Fernanda Freire de Oliveira

Flávio Amaral Oliveira

e correlatas utilizou-se a observação descritivamente no período vespertino e noturno e entrevistas.

Como procedimentos adotados, o estudo do tema deu-se pela pesquisa bibliográfica, através de informações primárias, como leis e normas sobre resíduos sólidos e como secundárias trabalhos científicos. Também foi utilizado procedimentos de observação e entrevistas. Foi aplicado um questionário com questões discursivas e de múltipla escolha ao diretor do instituição, para obter as informações sobre o campus e a geração de resíduos sólidos. E para a identificação dos RS gerados, foi realizada visita ao campus com registro fotográfico, no período vespertino e noturno, para identificar a cadeia produtiva dos RS (geração, disposição pelos frequentadores do campus, acondicionamento, armazenamento e destinação/disposição final).

\section{RESULTADOS E DISCUSSÕES}

\subsection{Situação do campus em relação às políticas de gestão de resíduos sólidos}

O campus da UNEMAT de Tangará da Serra - MT conta atualmente com sete cursos de graduação, sendo eles Administração com ênfase em Agronegócios, Administração com ênfase em Empreendedorismo, Agronomia, Ciências Biológicas, Ciências Contábeis, Enfermagem e Engenharia Civil, ofertados nos períodos diurnos e noturnos. Na universidade como consequência de todas as atividades operacionais do campus há a geração de resíduos sólidos, oriundos das atividades de limpeza, manutenção e conservação física e estrutural do campus, das atividades acadêmicas cotidianas e outras (palestras, eventos e seminários), das atividades da cantina e do consumo dos itens ali comercializados. E também das atividades de pesquisas e de aulas práticas efetuadas pelos cursos de Agronomia, Biologia e Enfermagem.

Em relação à geração de RS no campus, buscou-se diagnosticar primeiramente a atual situação, o que há de concreto implantado. Para tanto o primeiro questionamento foi acerca da Política Ambiental, se a instituição UNEMAT, está desenvolvendo ou implantando um Plano de Política Ambiental. A resposta pelo entrevistado foi negativa.

Neste aspecto Vedollo (1999, apud BROLLO e SILVA, 2001), a Política Ambiental “constitui o conjunto de diretrizes e princípios que devem nortear a definição e a aplicação de instrumentos legais e institucionais de planejamento e gerenciamento ambientais". Os autores 
Gestão de resíduos sólidos: um estudo de caso no campus universitário da UNEMAT de Tangará da Serra - MT

Fernanda Freire de Oliveira

Flávio Amaral Oliveira

ainda complementam que tais instrumentos influem nas tendências econômicas e sociais visando-se a realização do desenvolvimento sustentável.

Em complemento ao questionamento acima, perguntou-se, se há também alguma política específica para a geração de RS na instituição e/ou no campus de Tangará da Serra, o entrevistado informou que também não há. Caso a resposta fosse positiva, esta pesquisa poderia diagnosticar como o plano de gerenciamento de RS estaria funcionado, acompanhado da validação de critérios de certificação ambiental, como da ISO 14.001 e de conscientização ambiental por parte dos usuários envolvidos no processo.

Segundo Saito et. al (2011), a comunidade universitária tem papel fundamental nos assuntos ligados ao lixo e as decisões tomadas quanto a toda sua cadeia produtiva (geração, armazenamento e disposição), pois é uma contribuição vivencial que leva a construção e consciência ambiental por parte dos envolvidos.

O campus atualmente esta na contramão do que preceitua a PNRS, em seu Artigo $6^{\circ}$ (trata dos princípios da PNRS), incisos VII e VIII. O primeiro refere-se a responsabilidade compartilhada pelo ciclo de vida dos produtos a qual consiste em um conjunto de atribuições individualizadas e encadeadas dos envolvidos no processo de geração e consumo de RS, visando-se a minimização destes e também dos rejeitos gerados, além de reduzir os impactos causados à saúde humana e à qualidade ambiental decorrentes do ciclo de vida dos produtos.

Já o inciso VIII da PNRS compreende-se ao reconhecimento do resíduo sólido reutilizável e reciclável como um bem econômico e de valor social, gerador de trabalho e renda e promotor de cidadania. Ou seja, ter a percepção de que os RS tem o seu valor e desenvolver ações para a análise e aproveitamento de tais resíduos.

Quanto à coleta seletiva questionou-se, se o campus adota essa prática; se há algum convênio com a COOPERTAN (Cooperativa de Produção de Material Reciclável de Tangará da Serra) ou outra empresa para coleta destes materiais e se houve alguma campanha de conscientização sobre o tema. Também foi perguntado se há algum estudo sobre o volume de materiais recicláveis gerados no campus. Para todas as perguntas, o entrevistado afirmou não existir nada relacionado à coleta seletiva sendo desenvolvido no campus.

Neste aspecto é valido ressaltar que segundo Lima (2010) a UNEMAT de Tangará da Serra - MT teve participação ativa no apoio à formalização da COOPERTAN no município, pois no ano de 2008, a instituição firmou um Termo de Cooperação, em parceria com a 
Gestão de resíduos sólidos: um estudo de caso no campus universitário da UNEMAT de Tangará da Serra - MT

Fernanda Freire de Oliveira

Flávio Amaral Oliveira

Prefeitura Municipal e o Banco do Brasil, que levou o empreendimento a tornar-se de Utilidade Pública. Entretanto, hoje a instituição não está colaborando diretamente, já que não encaminha RS selecionados como recicláveis ao sistema da Coleta Seletiva da COOPERTAN.

A coleta seletiva facilita a gestão de RS, além de minimizar o impacto sobre o meio ambiente, é um poderoso instrumento para a redução do volume de resíduos sólidos urbanos, já que parte destes materiais poderão ser recicláveis ou reutilizáveis (SAITO et. al, 2011). Complementa o importante papel da coleta seletiva, um dos objetivos da PNRS, gerar a integração dos catadores de materiais reutilizáveis e recicláveis nas ações que envolvam a responsabilidade compartilhada pelo ciclo de vida dos produtos.

Questionou-se sobre as campanhas de conscientização sobre o tema coleta seletiva, também foi respondido que não houve nenhuma campanha esclarecedora prestada à comunidade acadêmica. Ressalta-se, que ainda que o campus não tenha implantado este sistema nas dependências da instituição, o município possui.

O programa Tangará Recicla é uma parceria do SAMAE e da COOPERTAN (LIMA, 2010) e foi institucionalizado em 2005. Portanto, identifica-se importante a participação da universidade no papel da educação e conscientização ambiental para disseminar o conhecimento teórico e práticos de temas que estão presentes no cotidiano social dos frequentadores do campus (acadêmicos, professores, servidores e terceirizados).

Vasconcelos et. al (2011), corrobora com o entendimento "uma universidade necessariamente promove a aproximação do indivíduo com a realidade na qual está inserida", nisso se faz um processo de educação”. As universidades são as pioneiras em pesquisa e desenvolvimento, pois direcionam o ensino à formação de cidadãos, podendo-se atribuir a elas a responsabilidade de educar para a criação de uma cultura sustentável (GOMES, 2009).

Também foi levantado a questão relacionada ao lixo eletrônico e a logística reversa. Em ambos os casos, identificou-se que não há nenhum convênio entre a instituição e empresas especializadas no recebimento de lixo eletrônico ou com empresas de logística reversa.

Já a logística reversa segundo a PNRS, é a forma mais segura de garantir que os itens classificados com maior potencial de toxicidade como pilhas, baterias e componentes eletrônicos, entre outros, sejam adequadamente destinado. 
Gestão de resíduos sólidos: um estudo de caso no campus universitário da UNEMAT de Tangará da Serra - MT

Fernanda Freire de Oliveira

Flávio Amaral Oliveira

\subsection{Geração e destinação dos resíduos sólidos gerados no campus}

Para a identificação do processo de geração e destinação dos resíduos sólidos, foram realizadas visitas ao campus no período vespertino e noturno no mês de Outubro e Novembro de 2013. Onde buscou-se observar os corredores da universidade, as salas de aulas, cantina, ou seja, os cenários de geração de RS.

A pesquisa identificou que o número de frequentadores no campus é de 2.448 entre acadêmicos, servidores, professores e terceirizados. A destinação dos RS gerados/consumidos por estes é representada pela Figura 2 e Figura 3. Os lixos são depositados pelos usuários diretamente em lixeiras, as quais são em sua maioria de plástico e estão sem tampas, algumas são aparentemente reaproveitamento de embalagens de produtos (item 2 da Figura 2). Quanto a lixeiras com separação dos materiais recicláveis, destinadas à coleta seletiva, localizou-se apenas uma (item 3, Figura 2), na área de entrada do Centro de Pesquisa, Estudos e Desenvolvimento Agro-Ambientais (CPEDA), contudo, a mesma não está sendo efetivamente usada e estas lixeiras estão sem a identificação do material que cada qual pode receber.

Figura 2-Lixeiras utilizadas no campus

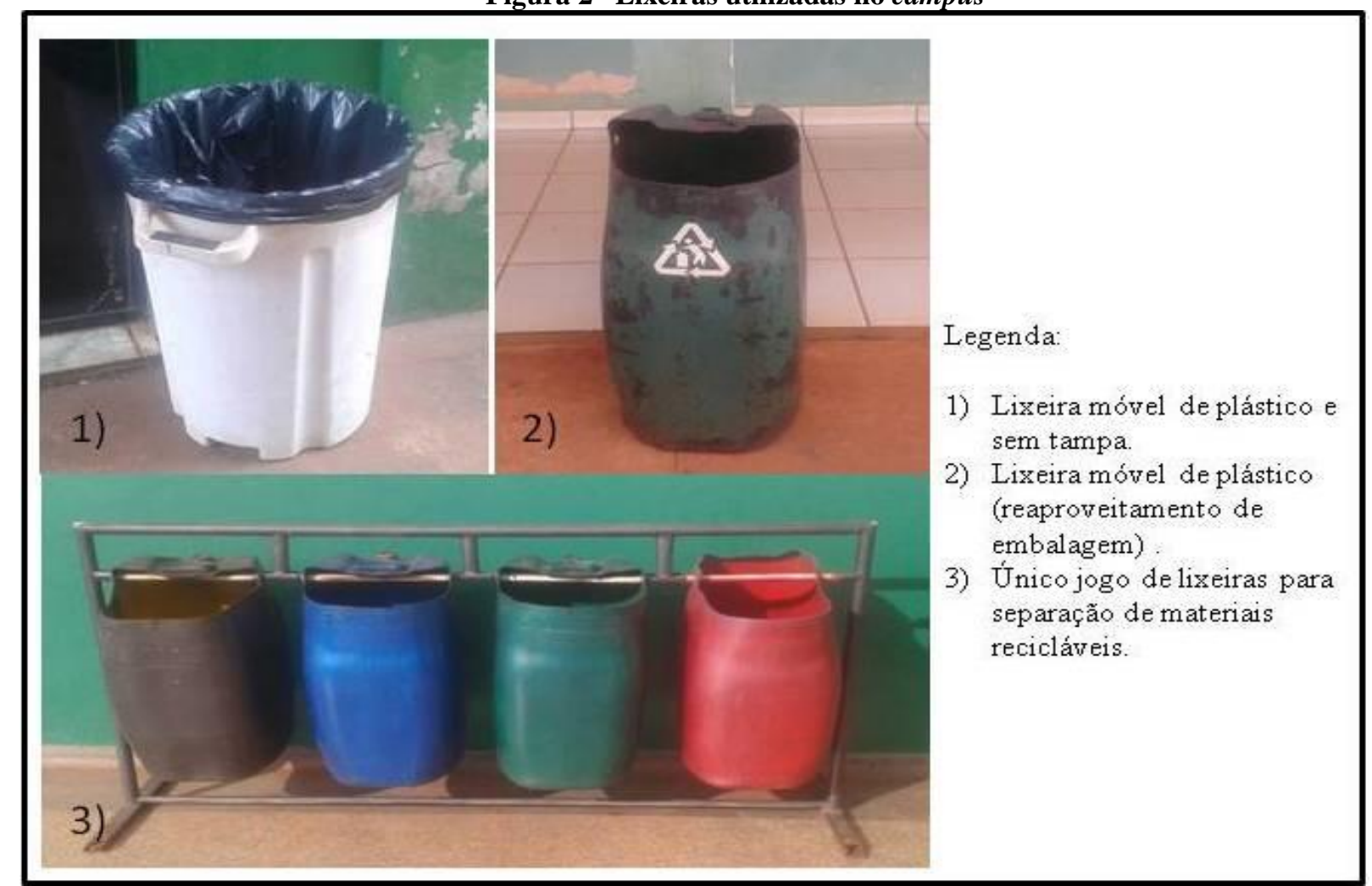

Fonte: dados da pesquisa (2013).

Volume 3, Número 5 Revista UNEMAT de Contabilidade

Jan./Jun. 2014

UNEMAT 
Gestão de resíduos sólidos: um estudo de caso no campus universitário da UNEMAT de Tangará da Serra - MT

Fernanda Freire de Oliveira

Flávio Amaral Oliveira

Através de inventário presencial, constatou-se que existem 32 lixeiras espalhadas pelo campus, conforme a Figura 4, abaixo. 
Gestão de resíduos sólidos: um estudo de caso no campus universitário da UNEMAT de Tangará da Serra - MT

Fernanda Freire de Oliveira

Flávio Amaral Oliveira

Figura 3 - Fluxograma frequentadores do campus e disposição das lixeiras

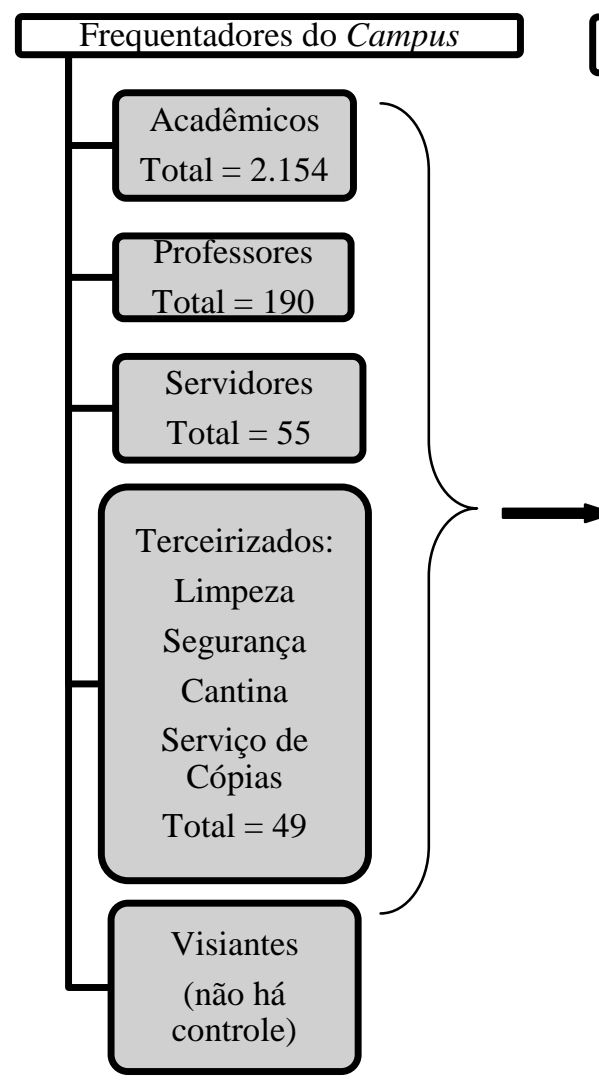

Total de Frequentadores $=2.448$
Locais de Disposição das Lixeiras

Frente do campus - 3 lixeiras fixas e 2 móveis:

Ponto de Ônibus - 1 lixeira móvel;

Corredor Central - 6 lixeiras fixas e 3 móveis;

Auditório - 1 lixeira móvel;

CPD (Centro de Processamento de Dados) - 1 móvel;

Cantina - 2 lixerias fixas e 3 móveis.

Corredor Pavilhão dos cursos

de Administração - 2 lixeiras móveis;

Corredor Pavilhão do curso de Letras -

3 lixeiras móveis;

Corredor Pavilhão dos cursos de

Contábeis,

Enfermagem e Engenharia Civil - 3

lixeiras móveis;

Corredor Pavilhão das salas dos

departamentos - 2 lixeiras móveis.

Total de lixeiras $=32$.

Fonte: dados da pesquisa (2013).

Uma vez depositado nas lixeiras, os resíduos destas são coletas pelos trabalhadores da empresa SELIGEL (terceirizada), responsável pela limpeza e manutenção de todos os campus da UNEMAT. Os resíduos são acondicionados em sacos plásticos grandes de lixo, da cor preta. Os sacos são encaminhados às áreas de "armazenamento (Figura 4)", as quais são lixeiras de porte maior, onde os resíduos recolhidos vão sendo acomodados. Ali, permanecem, até a coleta, a qual é feita duas vezes por semana pela empresa responsável pelo saneamento básico da região, o SAMAE (Serviço Municipal de Abastecimento e Esgoto). Todos os resíduos são destinados ao aterro sanitário do município. Sobre o volume de resíduos gerados no campus, questionou-se se há algum estudo elaborado de geração per capita de lixo, o entrevistado informou que não há.

Sobre a empresa terceirizada, foi identificado com o diretor administrativo do campus que todo o treinamento necessário sobre os processos de trabalho executados nos campus da UNEMAT em todo o estado, são de responsabilidade da empresa contrata, e não da instituição. 
Gestão de resíduos sólidos: um estudo de caso no campus universitário da UNEMAT de Tangará da Serra - MT

Fernanda Freire de Oliveira

Flávio Amaral Oliveira

Identificou-se três pontos de "armazenamento" conforme Figura 3, sendo 1) no setor frontal da universidade (nas proximidades do estacionamento da frente; 2) nos fundos da biblioteca (a caminho do alojamento estudantil) e 3) Em frente ao campo experimental de Agronomia/Biologia.

Figura 4 - Pontos de "armazenamento" dos RS antes da coleta pelo SAMAE

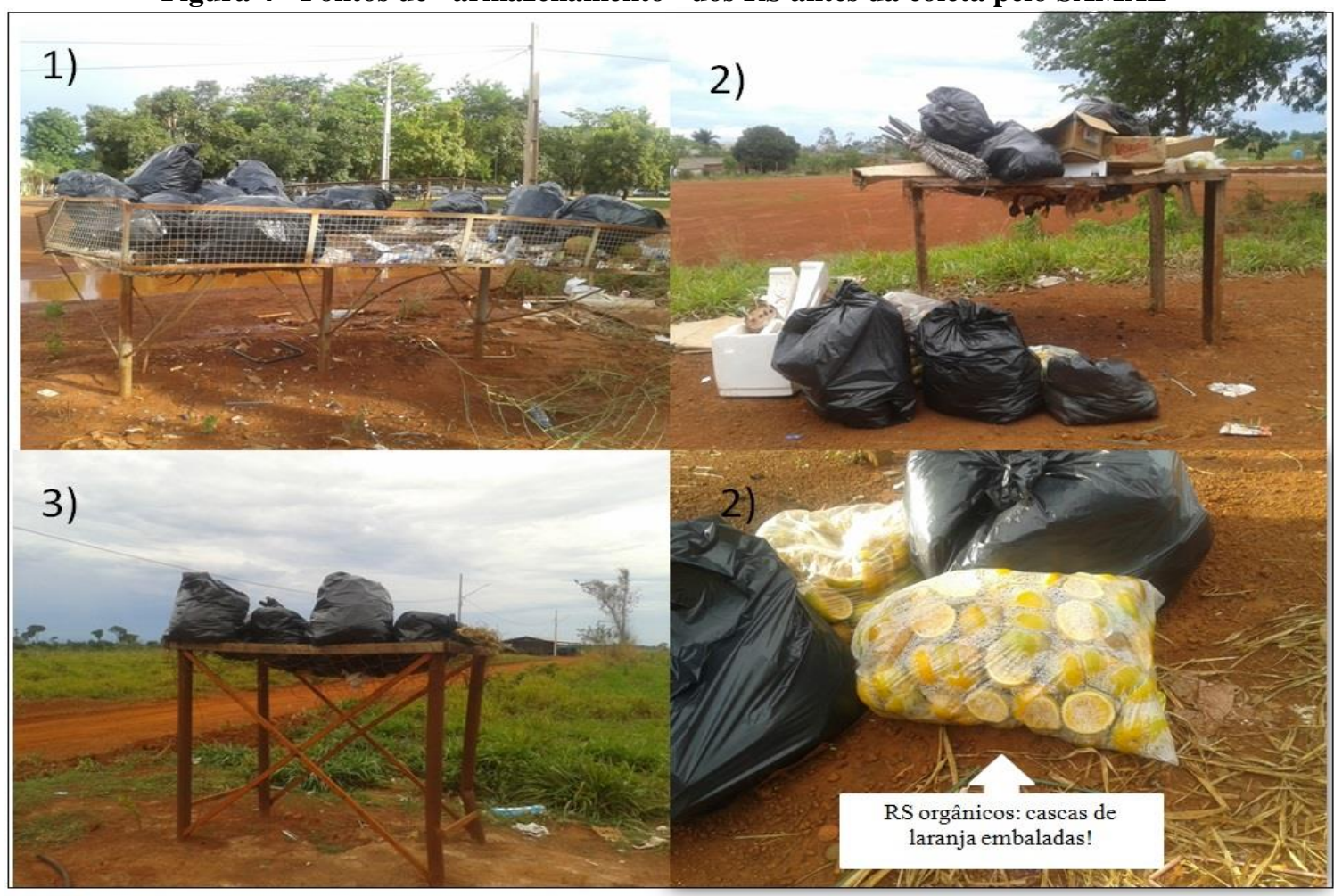

Fonte: dados da pesquisa (2013).

Para observar quais tipos de RS são gerados no campus, além de examinar o conteúdo das lixeiras dos ambientes descritos na Figura 1, foram escolhidos dois sacos, um saco no local $n^{\circ} 1$ e um saco do local $n^{\circ} 2$ de "armazenamento" (Figura 5). E pode-se constatar a presença dos itens descritos no Quadro 1 mais adiante.

A metodologia deu-se também através de visitas aos departamentos de Agronomia e Enfermagem. Em Agronomia, o chefe da coordenação do curso encontrava-se em viagem, e os questionamentos foram respondidos pela chefe do departamento de Fitopatologia. Já no departamento de Enfermagem, as dúvidas foram esclarecidas diretamente pelo chefe do departamento.

Quanto aos RS das atividades de pesquisa/práticas de Agronomia, basicamente identificou-se as embalagens plásticas de insumos agrícolas e os sacos plásticos de acondicionar sementes/adubos. Para o primeiro item, foi respondido que as embalagens 
Gestão de resíduos sólidos: um estudo de caso no campus universitário da UNEMAT de Tangará da Serra - MT

Fernanda Freire de Oliveira

Flávio Amaral Oliveira

encontram-se separadas e guardadas em um local específico no campus, porém, não foi autorizada a visita ao local.

Sobre o destino dado as embalagens plásticas de insumos agrícolas, foi explicado que por enquanto não é possível remeter ao ponto de recebimento do município o CEARPATANGARÁ (Conselho Estadual das Associações de Revenda de Produtos Agropecuários de Tangará da Serra), que possuí sua sede à Rodovia MT 358, km 2,5, Estrada Vicinal, na Zona Rural de Tangará da Serra, pois a maioria das embalagens vem de doações de empresas diversas. Neste caso, de acordo com o diretor da CEARPA-TANGARÁ, a entidade só pode receber as embalagens que comprovem a origem através de documento fiscal e este deve ser emitido por um associado à organização (revendedores e indústrias de insumos agrícolas). Já os sacos plásticos de acondicionar sementes/adubos são colocados junto com os demais resíduos coletados pela equipe da limpeza.

Nas atividades RS das atividades de pesquisa/práticas de Enfermagem, o coordenador informou que basicamente são resíduos para curativos e agulhas, os quais, ficam com os acadêmicos para dar uma destinação. Foi informado, que o volume destes materiais é pouco, uma vez que, os acadêmicos realizam estágios em instituições da saúde, onde realmente passam a ter contato mais expressivo com resíduos da saúde.

Para a identificação do lixo eletrônico produzido no campus, foram feitas entrevistas com dois envolvidos no processo, o Supervisor de Patrimônio e a Técnica do Laboratório de Informática. O lixo eletrônico foi identificado em dois grupos, os registrados no patrimônio e os suprimentos de informática. Os primeiros, após tornarem-se obsoletos para o uso e foram substituídos, passando a ser bens inservíveis do patrimônio da instituição, são computadores, impressoras, projetores, etc, (conforme Figura 5). Dependem da efetiva baixa no sistema patrimonial da instituição para receberem um destino, ainda não definido pelo campus. No momento, encontram-se armazenados em três salas anexas ao Clube Campestre do campus (Figura 5).

Os suprimentos de informática (mouses, teclados, caixa de som, etc.), não são registrados no patrimônio, e de acordo com a Técnica do Laboratório de Informática, no momento de inutilizar, são colocados em anexo ao lixo comum, para serem recolhidos pela equipe da limpeza. 
Gestão de resíduos sólidos: um estudo de caso no campus universitário da UNEMAT de Tangará da Serra - MT

Fernanda Freire de Oliveira

Flávio Amaral Oliveira

Para identificar uma possível solução ao lixo eletrônico, foi realizado entrevista com empresário do setor de informática da cidade. O mesmo informou, que não há no município e nem no estado, alguma empresa especializada na coleta destes materiais.

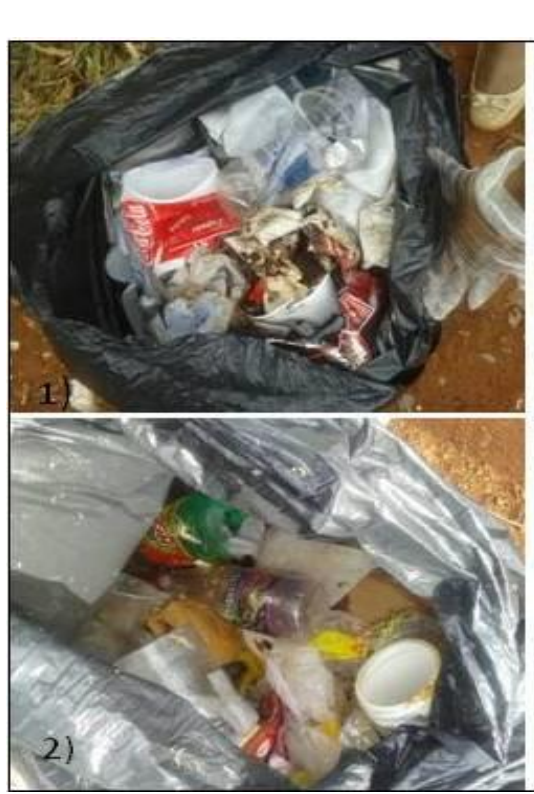

\section{Figura 5 - Amostras de RS e lixo eletrônico}

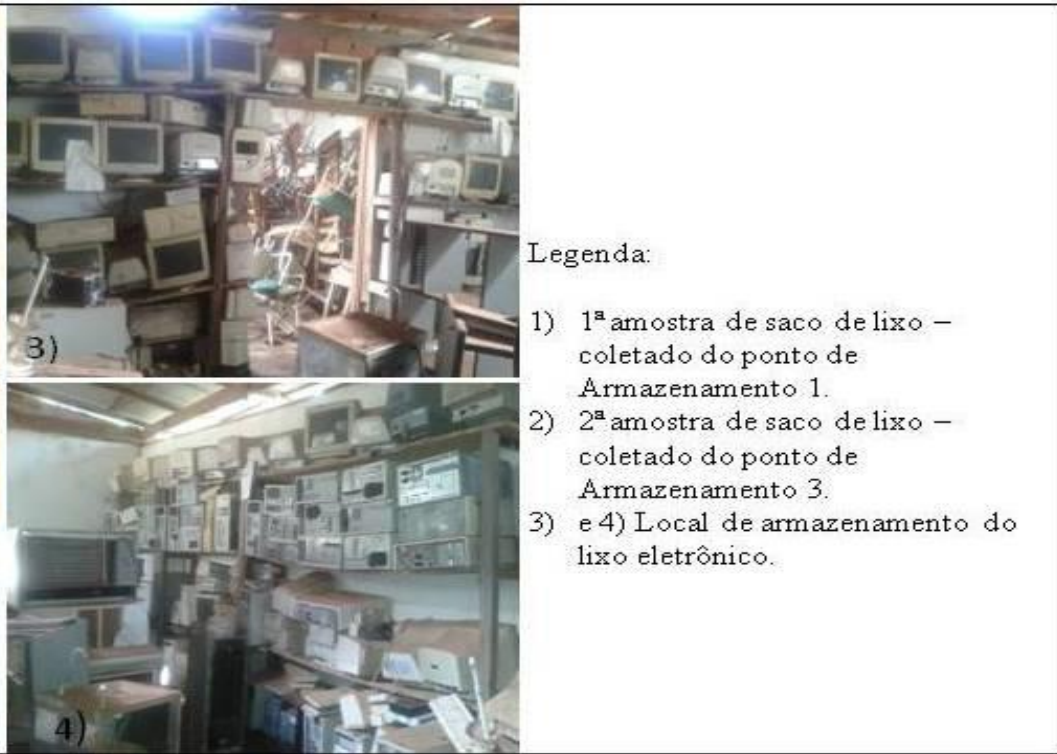

Fonte: dados da pesquisa (2013).

A partir da análise dos cenários descritos anteriormente, o Quadro 1 apresenta a lista dos RS gerados no campus, conforme a Lista Brasileira de Resíduos Sólidos.

Quadro 1 - Principais resíduos sólidos identificados pelas atividades no campus

\begin{tabular}{|c|c|c|}
\hline Fonte Geradora do RS & Descrição do Resíduo & $\begin{array}{l}\text { Capítulo de Classificação da Lista } \\
\text { Brasileira de RS }\end{array}$ \\
\hline $\begin{array}{l}\text { Atividades em geral } \\
\text { pedagógicas, } \\
\text { acadêmicas, cantina e } \\
\text { manutenção do campus }\end{array}$ & $\begin{array}{l}150101 \text { Embalagens de papel e cartão } \\
150102 \text { Embalagens de plástico } \\
150106 \text { Misturas de embalagens }\end{array}$ & $\begin{array}{l}15 \text { Resíduos de embalagens; absorventes, } \\
\text { panos de limpeza, materiais filtrantes e } \\
\text { vestuário de proteção não anteriormente } \\
\text { especificados. }\end{array}$ \\
\hline $\begin{array}{l}\text { Atividades em geral } \\
\text { pedagógicas, } \\
\text { acadêmicas, cantina e } \\
\text { manutenção do campus }\end{array}$ & $\begin{array}{l}200101 \text { Papel e cartão } \\
200108 \text { Resíduos biodegradáveis de cozinhas e } \\
\text { cantinas } \\
200139 \text { Plásticos } \\
200201 \text { Resíduos de varrição, limpeza de logradouros e } \\
\text { vias públicas e outros serviços de limpeza urbana } \\
\text { biodegradáveis }\end{array}$ & $\begin{array}{l}20 \text { Resíduos sólidos urbanos e equiparados } \\
\text { (resíduos domésticos, do comércio, } \\
\text { indústria e serviços), incluindo as frações } \\
\text { provenientes da coleta seletiva. }\end{array}$ \\
\hline $\begin{array}{l}\text { Atividades específicas } \\
\text { do curso de Agronomia }\end{array}$ & $\begin{array}{l}150110(*) \text { Embalagens de qualquer um dos tipos } \\
\text { acima descritos (itens } 150101 \text { e } 150102 \text { ) contendo ou } \\
\text { contaminadas por resíduos de substâncias perigosas }\end{array}$ & $\begin{array}{l}15 \text { Resíduos de embalagens; absorventes, } \\
\text { panos de limpeza, materiais filtrantes e } \\
\text { vestuário de proteção não anteriormente } \\
\text { especificados. }\end{array}$ \\
\hline $\begin{array}{l}\text { Atividades específicas } \\
\text { do curso de } \\
\text { Enfermagem }\end{array}$ & $\begin{array}{l}180111(*) \text { Recipientes e materiais resultantes do } \\
\text { processo de assistência à saúde, que não contenha } \\
\text { sangue ou líquidos corpóreos na forma livre } \\
180401(*) \text { Materiais perfurocortantes ou } \\
\text { escarificantes, tais como: lâminas de barbear, agulhas, } \\
\text { escalpes, ampolas de vidro, brocas, limas endodônticas, } \\
\text { pontas diamantadas, lâminas de bisturi, lancetas; [...] }\end{array}$ & 18 Resíduos de saúde \\
\hline $\begin{array}{l}\text { Equipamentos Elétricos } \\
\text { e Eletrônicos }\end{array}$ & $\begin{array}{l}200135 \text { (*) Produtos eletroeletrônicos e seus } \\
\text { componentes fora de uso não abrangido em } 200121 \mathrm{ou} \\
200123 \text { contendo componentes perigosos }\end{array}$ & $\begin{array}{l}\text { 20 Resíduos sólidos urbanos e equiparados } \\
\text { (resíduos domésticos, do comércio, } \\
\text { indústria e serviços), incluindo as frações } \\
\text { provenientes da coleta seletiva. }\end{array}$ \\
\hline
\end{tabular}

Volume 3, Número 5

Revista UNEMAT de Contabilidade

Jan./Jun. 2014

UNEMAT 
Gestão de resíduos sólidos: um estudo de caso no campus universitário da UNEMAT de Tangará da Serra - MT

Fernanda Freire de Oliveira

Flávio Amaral Oliveira

Fonte: dados da pesquisa (2013).

Considerando-se que o campus no momento atual não adota nenhuma política quanto à geração dos resíduos sólidos, a partir disto, o Quadro 2 levanta alguns dos principais itens não atendidos pela UNEMAT campus de Tangará da Serra quanto aos objetivos da Lei ${ }^{\circ}$ 12.305/2010, artigo sétimo, da PNRS.

. Buscou-se identificar qual (ais) seria (am) a (s) possível (eis) alternativas que o mesmo, poderia adotar, até que se desenvolva uma política para o tema em questão. Desta forma, constatou-se que a alternativa mais imediata ao alcance da instituição, é implantar a coleta seletiva, destinando os RS gerados por estas, a COOPERTAN. A qual faria a triagem dos materiais para selecionar os materiais que a mesma aproveita para reciclagem. E os demais materiais, seriam encaminhados ao aterro sanitário.

Quadro 2 - requisitos atendidos ou não pela UNEMAT de Tangará da Serra conforme à PNRS

\begin{tabular}{|c|c|c|c|}
\hline \multirow{2}{*}{$\begin{array}{l}\text { Inciso da } \\
\text { Lei }\end{array}$} & \multirow{2}{*}{ Descrição do objetivo da Lei } & \multicolumn{2}{|c|}{ Atende ao objetivo } \\
\hline & & Sim & Não \\
\hline II & $\begin{array}{l}\text { não geração, redução, reutilização, reciclagem e tratamento dos } \\
\text { resíduos sólidos, bem como disposição final ambientalmente adequada } \\
\text { dos rejeitos; }\end{array}$ & & $\mathrm{X}$ \\
\hline III & $\begin{array}{l}\text { estímulo à adoção de padrões sustentáveis de produção e consumo de } \\
\text { bens e serviços }\end{array}$ & & $\mathrm{X}$ \\
\hline VI & $\begin{array}{l}\text { incentivo à indústria da reciclagem, t endo em vista fomentar o uso de } \\
\text { matérias-primas e insumos derivados de materiais recicláveis e } \\
\text { reciclados; }\end{array}$ & & $\mathrm{X}$ \\
\hline VII & gestão integrada de resíduos sólidos & & $\mathrm{X}$ \\
\hline XII & $\begin{array}{l}\text { integração dos catadores de materiais reutilizáveis e recicláveis nas ações que } \\
\text { envolvam a responsabilidade compartilhada pelo ciclo de vida dos produtos }\end{array}$ & & $\mathrm{X}$ \\
\hline
\end{tabular}

Fonte: dados da pesquisa (2013).

Foi identificado na cidade através de visita, uma empresa denominada J.A Reciclagem, situada às margens do Anel Viário, a qual produz sacos plásticos de lixo, a partir de materiais plásticos descartados. Porém o proprietário da empresa explicou, que é preciso uma criteriosa seleção dos materiais plásticos recebidos. Pois nem todos são aproveitáveis, como exemplo, sacolas plásticas com pinturas impressas sobre as mesmas, plásticos da cor preta, entre outros. Em geral o que se aproveita são os plásticos transparentes, ou da cor branca como lonas, pois no processo de transformação de reciclagem estes materiais não danificam o maquinário utilizado, que terá como produto final, matéria prima para se produzir sacos de lixo. 
Gestão de resíduos sólidos: um estudo de caso no campus universitário da UNEMAT de Tangará da Serra - MT

Fernanda Freire de Oliveira

Flávio Amaral Oliveira

Percebe-se criteriosa a seleção dos materiais plásticos necessária para se encaminhar a esta indústria, demandando-se um trabalho maior, a aquele estabelecimento que pretende enviar a esta fábrica. Além de que, o proprietário afirmou, que também recebe materiais já inspecionados e não aproveitáveis pela COOPERTAN.

$\mathrm{Na}$ COOPERTAN, conforme visita realizada identificou-se que os materiais lá aproveitados são embalagens plásticas diversas (sacolas, embalagens de produto de limpeza, etc.), garrafas pets em todas as cores, papelão, papel, ferro e alumínio. O processo dá-se da seguinte forma: 1) os caminhões do programa Tangará Recicla depositam os sacos coletados num ponto específico aos fundos do barracão onde é fica a esteira de triagem; 2) uma equipe de cooperados faz a seleção dos materiais que serão aproveitados e deposita-os em sacos grande do tipo "Big Bag", e estes sacos são encaminhados à esteira para triagem; 3) Na mesa de triagem, os cooperados separados por características como cor, densidade, tamanho e peso e colocam novamente em sacos de "Big Bag" os quais são encaminhados para próximo da máquina de que compensa os resíduos.

Figura 6 - Processo separação de RS na COOPERTAN Tangará da Serra - MT

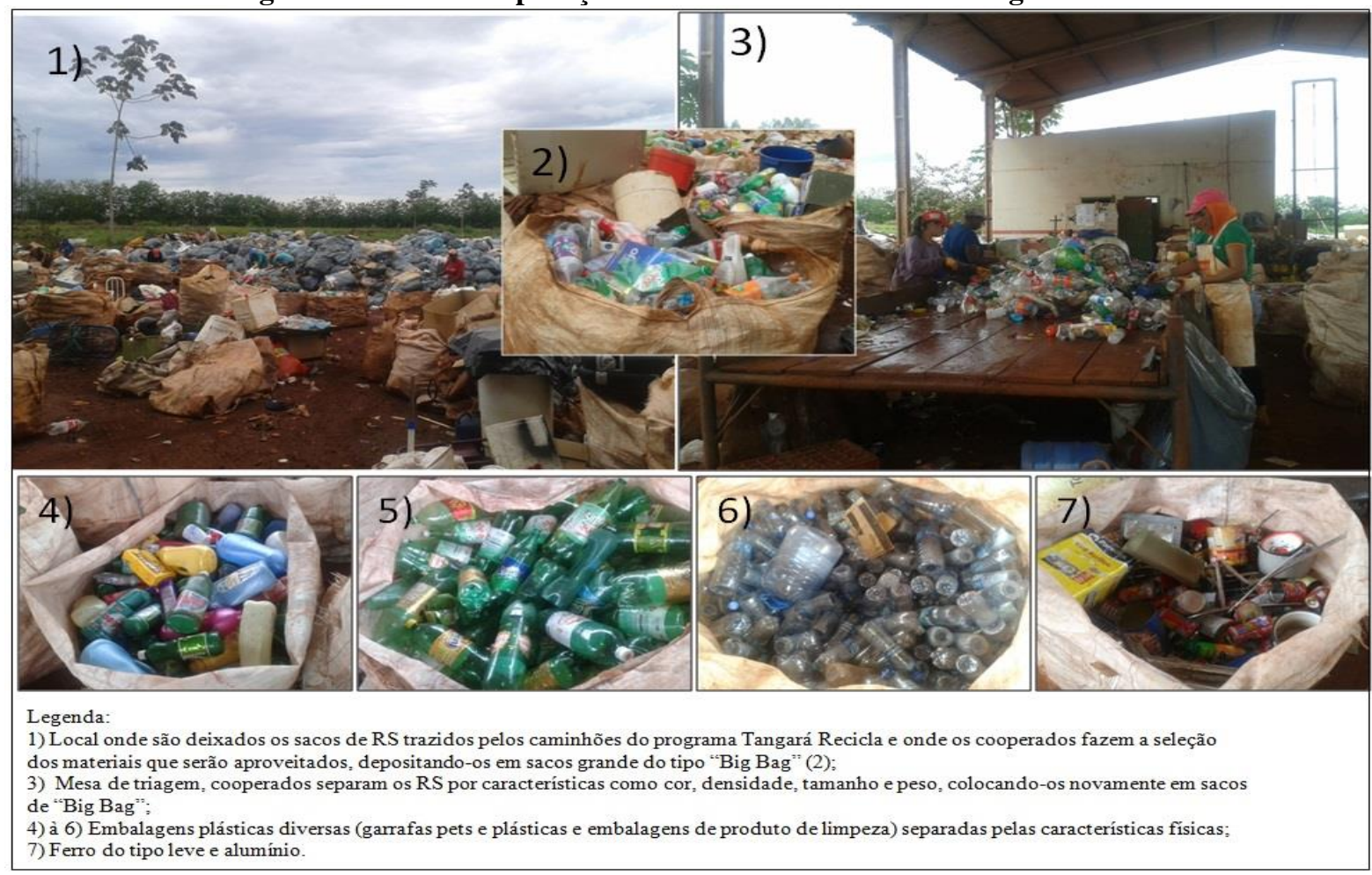

Fonte: dados da pesquisa (2013).

O próximo processo é a compensa dos resíduos conforme a Figura 8, abaixo: 
Gestão de resíduos sólidos: um estudo de caso no campus universitário da UNEMAT de Tangará da Serra - MT

Fernanda Freire de Oliveira

Flávio Amaral Oliveira

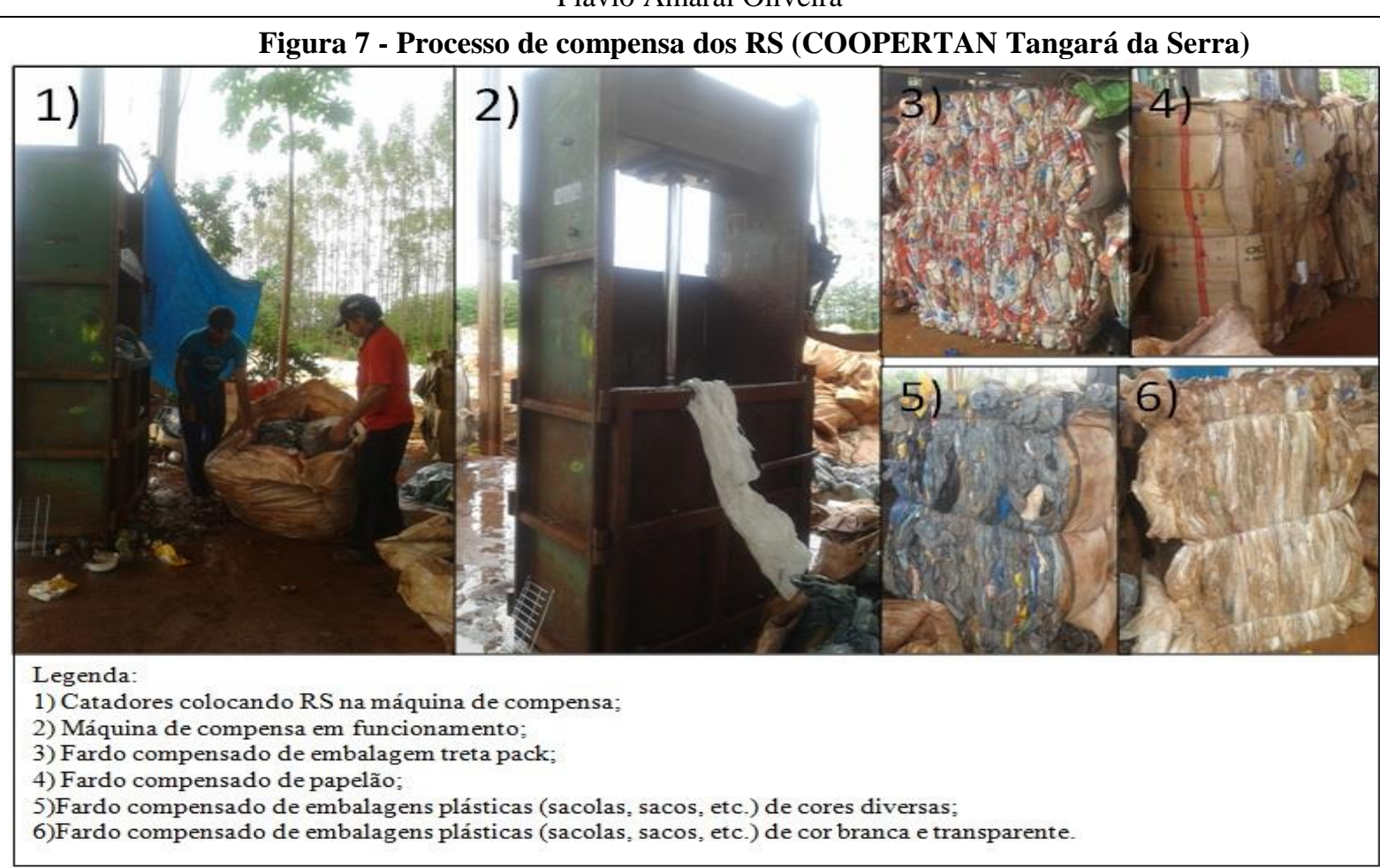

Fonte: dados da pesquisa (2013).

Os fardos de garrafas pets em todas as cores, papelão e papel são encaminhados a uma empresa em Cuiabá e de lá destinados às fábricas que fazem o processo de reciclagem. $\mathrm{O}$ ferro e alumínio, são destinados a terceiros dentro do município. Nenhuma das empresas receptoras dos materiais compensados foram identificadas.

Em entrevista ao diretor administrativo do SAMAE que é o gestor do programa Tangará Recicla, foi explicado que o campus pode aderir a participação ao projeto, para tanto se faz necessário que a instituição adote os sacos de lixo do projeto, pois estes são a forma de identificar-se que aqueles materiais são destinados a reciclagem.

Como foi mencionado anteriormente os principais materiais que à COOPERTAN aproveita, é válido ressaltar que além de instalar o programa de coleta seletiva no campus, percebe-se importante que se tenha uma área de triagem local, para assim apenas destinar à cooperativa, os RS que serão realmente aproveitados.

\section{CONSIDERAÇÕES FINAIS}

Os resultados da pesquisa, apontam, que o campus da UNEMAT de Tangará da Serra MT, no momento atual, precisa adequar-se quanto as responsabilidades descritas na Política Nacional de Resíduos Sólidos. Contudo vale ressaltar que mesmo sem existir uma política de 
Gestão de resíduos sólidos: um estudo de caso no campus universitário da UNEMAT de Tangará da Serra - MT

Fernanda Freire de Oliveira

Flávio Amaral Oliveira

RS estabelecida no campus, é possível adotar-se práticas que poderão contribuir à futura adequação da instituição. Uma delas seria a adoção da coleta seletiva. Com a qual pode-se encaminhar os resíduos sólidos recicláveis a COOPERTAN, onde é feito o trabalho de seleção e o devido aproveitamento para encaminhamento à reciclagem.

Os resultados mostram que quanto ao objetivo geral: identificou-se que não há a adoção de práticas de gestão de resíduos sólidos adotadas no campus da UNEMAT de Tangará da Serra - MT. E em relação aos objetivos específicos: identificou-se no que tange a legislação de resíduos sólidos a Política Nacional de Resíduos Sólidos (PNRS), instituída pela Lei n $n^{\circ}$ 12.305/2010; identificou-se que não existe na instituição e no campus de Tangará da Serra - MT, nenhum programa de gestão de resíduos sólidos implantado; identificou-se que os principais resíduos sólidos gerados são: embalagens diversas (papel, cartão e plástico), misturas de embalagens, papel, cartão e resíduos biodegradáveis da cantina e identificou-se que todos os RS são destinados ao aterro sanitário do município.

Como sugestões de melhorias à pesquisa, propõe-se o levantamento quantitativo dos principais resíduos sólidos (recicláveis e reutilizáveis) gerados pelas atividades acadêmicas e pedagógicas, objetivando-se a mensuração econômica para a implantação de alternativas a destinação destes resíduos e propõe-se também a extensão da pesquisa a universidade como um todo, verificando-se qual situação da UNEMAT ante a geração de resíduos sólidos nos dias de hoje e o que a mesma projeta para o futuro.

\section{REFERÊNCIAS BIBLIOGRÁFICAS}

ASSOCIAÇÃO BRASILEIRA DE NORMAS TÉCNICAS. NBR 10.004/04 - Resíduos Sólidos: Classificação - 2a ed. Rio de Janeiro, 2004.

ASSOCIAÇÃO BASILEIRA DE EMPRESAS DE LIMPEZA PÚBLICA E RESÍDUOS ESPECIAIS. Panorama dos Resíduos Sólidos no Brasil 2012 - 10 ed.. Disponível em < http://www.abrelpe.org.br/Panorama/panorama2012.pdf>. Acesso em Outubro 2013.

ASSUMPÇÃO, Luiz Fernando Joly; Sistema de Gestão Ambiental: manual prático para implementação de SGA e Certificação ISO 14.001. Curitiba: Jurua, 2005.

BRASIL. Ministério do Meio Ambiente. Conselho Nacional do Meio Ambiente. Resolução CONAMA no 001, de 23 de janeiro de 1986. Disponível em

<http://www.mma.gov.br/port/conama/res/res86/res0186.html>. Acesso em Junho 2013. 
Gestão de resíduos sólidos: um estudo de caso no campus universitário da UNEMAT de Tangará da Serra - MT

Fernanda Freire de Oliveira

Flávio Amaral Oliveira

Presidência da República. Casa Civil. Lei no 12.305, de 02 de agosto de 2010.

Institui a Política Nacional de Resíduos Sólidos. Disponível em < http://www.planalto.gov.br/ccivil_03/_ato2007-2010/2010/lei/112305.htm >. Acesso em Setembro 2013.

Instituto Nacional do Meio Ambiente. Instrução Normativa No 13 , de 18 de Dezembro de 2012. Lista Brasileira de Resíduos Sólidos. Disponível em < http://www.ibama.gov.br/phocadownload/category/5?download=6712\%3Alistabrasileiraderes iduossolidostexto>. Acesso em Outubro 2013.

BROLLO, Maria José; SILVA, Mirtes Moreira. Política e Gestão Ambiental. Revisão e Análise sobre a atual situação no Brasil. 21 Congresso Brasileiro de Engenharia Sanitária e Ambiental, 2001. Disponível em <http://www.bvsde.paho.org/bvsaidis/brasil21/vi078.pdf> . Acesso em Setembro 2013.

BUSH, Susanna Erica; RIBEIRO, Helena. Responsabilidade socioambiental empresarial: revisão da literatura sobre conceitos. Revista de Gestão Integrada em Saúde do Trabalho e Meio Ambiente, v. 4, n. 2, Artigo 1, maio/ago 2009. Disponível em <http://www.revistas.sp.senac.br/index.php/ITF/article/viewFile/33/64>. Acesso em Novembro 2013.

CUNHA, Valeriana; CAIXETA FILHO, José Vicente. Gerenciamento da coleta de resíduos sólidos urbanos: estruturação e aplicação de modelo não-linear de programação de metas. Gestão \& Produção, v. 9, n. 2, p. 143-161, 2002. Disponível em < http://www.scielo.br/pdf/gp/v9n2/a04v09n2.pdf>. Acesso em Novembro 2013.

DEMAJAVORIC, Jacques. Da política tradicional de tratamento do lixo à política de gestão de resíduos sólidos: as novas prioridades. Revista de Administração de Empresas, v. 35, n. 3, p. 88-93, Mai./Jun.1995. Disponível em <www.scielo.br/pdf/rae/v35n3/a10v35n3.pdf>. Acesso em Outubro 2013.

DIAS, Reinaldo. Gestão ambiental: responsabilidade e sustentabilidade. 1. ed.São Paulo: Atlas, 2006.

FERREIRA, Aracélia Cristina de Sousa. Contabilidade ambiental: uma informação para o desenvolvimento sustentável. São Paulo: Atlas, 2003.

FERREIRA, Aldo Pacheco; SOARES, Bernardo Elias C.; NAVARRO, Marli Albuquerque. Desenvolvimento Sustentado e consciência ambiental: natureza, sociedade e racionalidade.

Ciência \& Cognição, Vol. 02, p. 42-49, Jul/2004. Disponível em < http://www.cienciasecognicao.org/revista/index.php/cec/article/download/29/22>. Acesso em Maio 2013.

GOMES, Patrícia Caroline G.. Diagnóstico de Resíduos Sólidos da Puc-Rio. Rio de Janeiro: PUC-Rio, 2009. Disponível em < http://www.nima.pucrio.br/monografias/diagnostico_dos_Residuos_Solidos_do_Campus_da_PUC-Rio.pdf >. Acesso em Setembro, 2013.

JACOBI, Pedro. Educação Ambiental, Cidadania e Sustentabilidade. Cadernos de Pesquisa. 
n. 118, p. 189-205, março/2003. Disponível em

<http://www.scielo.br/pdf/cp/n118/16834.pdf>. Acesso em Junho 2013.

JÚNIOR CASAGRANDE, Eloy Fassi; DEEKE, Vania. Implantando práticas sustentáveis nos campi universitários: a proposta do "escritório verde" da UTFPR. Disponível em $<$ http://revistas.utfpr.edu.br/pb/index.php/revedutec-ct/article/view/1102/706>. Acesso em Junho 2013.

KRAEMER, Maria Elisabeth Pereira. A universidade do século XXI rumo ao desenvolvimento sustentável. Disponível em $<$ http://revistas.facecla.com.br/index.php/recadm/article/view/408/306>. Acesso em Abril 2013.

LIMA, Ana Maria. Análise da Transição do Trabalho Individual para o trabalho coletivo em cooperativas de reciclagem de resíduos: um estudo de caso da Coopertan de Tangará da Serra - MT. Tese. São Carlos: UFSCar, 2010. Disponível em <

http://www.bdtd.ufscar.br/htdocs/tedeSimplificado//tde_busca/arquivo.php?codArquivo=3280 >. Acesso em Outubro 2013.

OLIVEIRA, Otávio José de; PINHEIRO, Camila Roberto Muniz S. Implantação de sistemas de gestão ambiental ISO 14001: uma contribuição da área de gestão de pessoas. Gestão \& Produção, v. 17, n. 1, p. 51-61, 2010. Disponível em < http://www.scielo.br/pdf/gp/v17n1/v17n1a05.pdf>. Acesso em Junho 2013.

SAITO, Carlos Hiroo at. al. Agenda 21 da Universidade de Brasília e a caracterização dos resíduos domésticos no campus Darcy Ribeiro. In: CATALÃO, Margarida Vera et. al. Universidade para o século XXI: educação e gestão ambiental na Universidade de Brasília. Brasília: Cidade Gráfica e Editora, 2011.

TAUCHEN, Joel; BRANDLI, Luciana Londero. A gestão ambiental em instituições de ensino superior: modelo para implantação em campus universitário. Gestão \& Produção, v. 13, n. 3, p.503-515, Set-Dez/2006. Disponível em <http://www.scielo.br/pdf/gp/v13n3/11.pdf >. Acesso em Abril 2013.

TINOCO; João Eduardo Prudêncio; KRAEMER, Maria Elisabeth Pereira. Contabilidade e gestão ambiental. São Paulo: Atlas, 2004.

VASCONCELOS, Joaquim Pedro R. at. al. Para, pense e descarte: coleta seletiva solidária. In: CATALÃO, Margarida Vera et. al. Universidade para o século XXI: educação e gestão ambiental na Universidade de Brasília. Brasília: Cidade Gráfica e Editora, 2011. 